\title{
Uji Antagonis Jamur Trichoderma viride dalam Menghambat Pertumbuhan Jamur Patogen Alternaria porri Penyebab Penyakit Bercak Ungu pada Tanaman Bawang Merah (Allium ascalonicum L.)
}

\author{
Fungi Antagonism Test of Trichoderma viride in Inhibiting Growth \\ Pathogenic Fungi of Alternaria porri that causes of the Purple Spot on \\ Shallots (Allium ascalonicum L.) \\ Vira Ruainiah Ruswandari ${ }^{1 *}$, Ahmad Syauqi ${ }^{2 * *}$, Tintrim Rahayu ${ }^{3}$ \\ ${ }^{123)}$ Jurusan Biologi Fakultas Matematika dan Ilmu Pengetahuan Alam, Universitas Islam Malang, Indonesia
}

\begin{abstract}
ABSTRAK
Jamur Trichoderma viride merupakan mikroorganisme yang umum dijumpai dalam tanah yang lembab dan dapat diisolasi dari daerah perakaran tanaman bawang merah (Allium ascalonicum L.) Penelitian bertujuan untuk mengetahui mekanisme dan perbedaan persentase daya hambat oleh jamur Trichoderma viride dalam menghambat pertumbuhan patogen Alternaria porri pada $\mathrm{pH}$ 4,8 dan 7. Metode yamg digunakan metode deskriptif dengan mengisolasi jamur Alternaria porri dan Trichoderma viride lalu dimurnikan, dan metode eksperimen melakukan uji antagonis jamur Trichoderma viride terhadap Alternaria porri dengan dua perlakuan media PDA pH 4,8 yamg diaamati selama 3 hari dan $\mathrm{pH} 7$ yang diamati selama 4 hari. Hasil persentase daya hambat pada hari ke 1,2,3 yaitu 9\%,34,2\% dan 35\% (pH 4,8), dan hasil persentase daya hambat hari ke 1,2,3 dan 4 yaitu 1,9\%, 29,9\%, 35\% dan 39,4\% (pH 7). Hal ini diketahui bahwa hasil terakhir persentase daya hambat $35 \%(\mathrm{pH} 4,8)$ dan 39,4\% ( $\mathrm{pH} 7$ ). Mekanisme Penghambatan Jamur Trichoderma viride dalam menghambat jamur Alternaria porri melalui tahap antibiosis, parasitisme dan lisis.
\end{abstract}

Kata kunci: Trichoderma viride, Alternaria porri, tanaman bawang merah, pH 4,8 dan pH 7.

\begin{abstract}
Trichoderma viride is a microorganism that is commonly found in moist soil and can be isolated from the root area of the shallot plant (Allium ascalonicum L.). The study aim was to determine the mechanism and the difference in percentage of inhibitory power by Trichoderma viride in inhibiting growth of Alternaria porri pathogen at $\mathrm{pH} 4.8$ and 7. The descriptive method was used by descriptive method to isolate Alternaria porri and Trichoderma viride fungi and then purified, and the experimental method tested Trichoderma viride fungal antagonists against Alternaria porri with two PDA media treatments $\mathrm{pH} 4.8$ that observed for 3 days and $\mathrm{pH} 7$ observed for 4 days. The results of the percentage of inhibitory power on the day 1,2,3 were 9\%, 34.2\% and

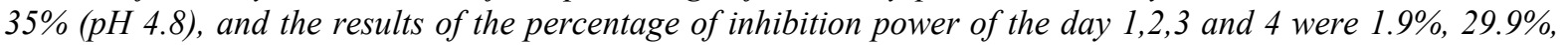
$35 \%$ and $39.4 \%(\mathrm{pH} 7)$. The inhibition mechanism of Trichoderma viride in inhibiting Alternaria porri fungi through the stages of antibiosis, parasitism and lysis.
\end{abstract}

Keywords: Trichoderma viride, Alternaria porri, shallot plants, $\mathrm{pH} 4.8$ and $\mathrm{pH} 7$.

\footnotetext{
*) Vira Ruainiah Ruswandari. Jurusan Biologi FMIPA Universitas Islam Malang, Jl. MT Haryono 193, Malang 65144, 085231085937, e-mail: Vieraruainiah@gmail.com

${ }^{* *}$ Ir. Ahmad Syauqi, M.Si. Jurusan Biologi FMIPA UNISMA, Jl. MT Haryono 193, Malang 65144, 08986307836, e-mail:ahmadandro.as@gmail.com
}

Diterima Tanggal 20 Juli 2019 - Diterbitkan Tanggal 25 Januari 2020 


\section{Pendahuluan}

Tanaman bawang merah (Allium ascalonicum L.) merupakan salah satui jenis tanaman komoditas hortikultura. Tanaman bawang merah juga memiliki arti penting dalam kehidupan sehari-hari untuk masyarakat indonesia karena dapat dimanfaatkan sebagai bumbu masakan ataupun obat tradisional [1]. Bawang merah (Allium ascalonicum L.) adalah tanaman semusim yang tumbuhnya membentuk rumpun, tumbuhnya tegak dan tingginya bisa mencapai $15-50 \mathrm{~cm}$. Bentuk perakarannya berupa akar serabut. Warna daun hijau dan memiliki rongga, memilik batang sejati atau disebut dengan discus, bentuknya menyerupai cakram tipis dan pendek yang berfungsi untuk tempat melekatnya perakaran dan mata tunas. Umbi tanaman bawang merah per rumpunnya memiliki jumlah yang bervariasi antara 4-8 bahkan bisa mencapai 35 umbi, dan memiliki warna yang bervariasi yaitu ungu keputihan, coklat, merah bahkan ada yang berwarna kuning dengan bentuk mulai dari gepeng hingga bulat [2]. Begitu banyak kendala dalam meningkatkan produksi tanaman bawang merah salah satu kendala yang sangat penting dan sering kita jumpai yaitu adanya penyakit bercak ungu yang disebabkan oleh jamur patogen Alternaria porri [3]. Penyebab dari penyakit bercak ungu yang disebabkan patogen Alternaria porri pada tanaman bawang merah ini mengakibatkan kerugian yang cukup tinggi bagi para petani [1]. Jamur Alternaria porri biasanya menyerang pada bagian daun tanaman bawang merah namun pada kondisi tertentu jamur tesebut juga dapat menyerang batang maupun pada umbi [4].

Dalam pengendalian serangan jamur Alternaria porri pada tanaman bawang merah begitu banyak upaya yang dillakukan untuk mengatasi jamur patogen tersebut, diantaranya yaitu penggunaan fungisida sintesis. Namun pengendalian dengan menggunakan fungisida sintesis masih kurang efektif dan dapat memberikan dampak negatif karena residu dari fungisida tersebut dapat mencemari lingkungan. Maka penanganan yang baik dan tepat bagi lingkungan dan tanaman yaitu dengan pemanfaatan mikroba sebagai biopestisida yang biasa dikenal dengan mikroba antagonis. Salah satu mikroorganisme yang baik digunakan sebagai biopestisida yaitu jamur Trichoderma viride. Trichoderma viride termasuk jenis jamur yang berkembang biak dengan cepat didaerah perakaran. Dan juga merupakan kelompok jamur tanah yang telah tersebar diseluruh dunia, sering ditemukan pada tanah yang lembab dan sering terdapat ditanah gambut [5]. Jamur Trichoderma sp merupakan jamur yang mampu dan juga berpotensi dalam mengendalikan penyakit yang disebabkan oleh patogen [6]. Beberapa peneliti menyatakan bahwa jamur Trichoderma sp. merupakan jamur yang mampu dijadikan sebagai agens dalam mengendalikan patogen secara hayati, dan mekanisme yang jamur Trichoderma sp lakukan dalam menghambat pertumbuhan jamur patogen ialah denga mekanisme parasitime, kompetisi, antibiosis dan lisis. mekanisme antagonis Trichoderma sp. terhadap jamur patogen dilakukan dengan cara mengeluarkan toksin yang berupa enzim $\beta-1,3$ glukanase, selulase dan kitinase yang mampu menghambat pertumbuhan dan bahkan mampu membunuh jamur patogen. Jamur spesies ini juga dapat dimanfaatkan sebagai pengendali hayati yang bersifaat ramah lingkungan [7]. Jamur Trichoderma viride ini hidup sebagai paeasit dan menyerang jamur yang lain cara mengambil nutrisinya [2].

Berdasarkan hal tersebut maka perlu dilakukan penelitian mengenai upaya pengendalian yang lebih efektif dan ramah lingkungan dengan menggunakan jamur Trichoderma viride. Dalam hal ini jamur Trichoderma viride diamati potensinya sebagai agen pengendali penyakit pada tanaman bawang merah. Pada penelitian uji antagonis ini dilakukan untuk mengamati kemampuan jamur Trichoderma viride dalam menghambat pertumbuhan patogen Alternaria porri yang menyerang tanaman bawang merah.

\section{Material dan Metode}

\section{Alat dan Bahan}

Alat digunakan Kamera, ATK, Autoklaf, Inkubator, Timbangan analitik, Cawan petri steril, Pinset steril, Erlenmeyer $250 \mathrm{ml}$, Gelas beaker, Laminar Air Flow (LAF), Hotpleta magnetik stirerr, Oven, Cutter, pH meter, Bunsen, Korek, Kompor gas, tabung elpigi, mikroskop, Kertas sampul, Kapas, Spatula, Spiritus, Benang kasur, Karet, Kertas label, Tissue, jarum ose dan Wrapping.

Bahan yang digunakan dalam penelitian ini yaitu Jamur Trichoderma viride yang diperoleh dari hasil isolasi pada tanah bagian akar tanaman bawang merah, dan jamur patogen Alternaria porri juga 
diperoleh dari isolasi pada bagian daun yang berpenyakit pada tanaman bawang merah, PDA (Potato Dextro Agar) bubuk yang digunakan sebagai media pertumbuhan jamur pada saat isolasi, Aquades, PBS (Posfat Buffer Saline), Asam posfat $\left(\mathrm{H}_{3} \mathrm{PO}^{4}\right)$, Natrium hidroksida $(\mathrm{NaOH})$, Alkohol 70\%.

\section{Metode}

Metode yang digunakan dalam penelitian ini adalah metode deskriptif yang meliputi penelitian pendahuluan yaitu mengisolasi jamur patogen Alternaria porri dan Trichoderma viride kemudian dimurnikan terlebih dahulu, lalu di uji antagonis jamur Trichoderma viride terhadap Alternaria porri. Dan metode eksperimen mempunyai dua perlakuan yaitu media PDA (Potato Dextrose Agar) pada pH 4,8 dan $\mathrm{pH} 7$ sebagai media pertumbuhan jamur yang diuji antagonis dengan 5 kali ulangan.

\section{Cara Kerja}

Persiapan: Sterilisasi alat: Sterilisasi alat dan bahan yang dilakuakan dengan cara membungkus alatalat dengan kertas sampul, lalu dimasukkan kedalam autoklaf pada suhu $121^{\circ} \mathrm{C}$ selama 15 menit. Pembuatan media: Pembuatan media PDA pada $\mathrm{pH} 4,8$ dan $\mathrm{pH} 7$ digunakan untuk uji antagonis, dan untuk mengisolasi jamur Trichoderma viride dan Alternaria porri yaitu dengan menimbang media PDA bubuk dan dilarutkan dengan aquades steril. Masing-masing media dicairkan kedalam erlenmeyer. Kemudian dididihkan dengan menggunakan hot plate hingga mendidih dan homogen, kemudian disterilisasi dengan menggunakan autoklaf pada suhu $121^{\circ} \mathrm{C}$. Saat suhu dan tekanan telah tercapai, dibiarkan selama 15 menit. Lalu medium dituangkan pada cawan petri yang telah disiapkan \pm sebanyak $10 \mathrm{~mL}$ secara aseptis.

Isolasi jamur patogen Alternaria porri: Isolasi jamur patogen dilakukan dengan cara memotong bagian daun kira-kira $1 \mathrm{~cm}$ yang terserang penyakit, dibersihkan dengan aquades steril dan dengan alkohol $70 \%$, kemudian dibersihkan kembali dengan aquades steril. Selanjutnya diletakkan pada permukaan media PDA (Potato Dextro Agar) dan diinkubasi selama \pm 5 hari pada suhu ruang. Isolasi jamur Trichoderma viride: Isolasi jamur Trichoderma viride dilakukan dengan menggunakan metode pengenceran. Sampel tanah yang diperoleh dari bagian akar tanaman bawang merah yang sehat kemudian ditimbang sebanyak 1 gram dan dimasukkan kedalam tabung reaksi yang telah berisi aquades steril $10 \mathrm{ml}$ lalu dihomogenkan. Kemudian tanah yang diencerkan diambil menggunakan pipet tetes steril sebanyak $1 \mathrm{ml}$, dan dituang kedalam media PDA (Potato Dextro Agar) lalu digoyang hingga larutan enceran tanah merata pada media tanam dan diinkubasi \pm 5 hari pada suhu ruang.

Pemurnian Jamur Patogen Alternaria porri dan Jamur Trichoderma viride: Jamur patogen yang telah tumbuh pada media isolasi PDA (Potato Dextro Agar), kemudian dimurnikan pada media PDA baru dengan menggunakan jarum ose, jika jamur yang tumbuh bercampur dengan jamur yang lain maka dilakukan purifikasi kembali, dan hal ini bertujuan untuk memperoleh isolat jamur patogen yang murni. Jamur patogen diinkubasi selama \pm 5 hari.

\section{Pembiakan Jamur Trichoderma sp. dan Alternaria porri}

Perbanyakan jamur Trichoderma sp dan Alternaria porri dilakuakan dalam LAF (Laminar Air Flow) dengan menumbuhkan isolat pada media PDA cawan petri dan media miring. Isolat jamur Trichoderma sp dan Alternaria porri diambil dengan menggunakan jarum ose yang kemudian diinokulasuikan ke dalam media PDA. Selanjutnya di inkubasi selama \pm 5 hari dengan suhu ruangan. Agar tidak terkontaminasi saat perbanyakan jamur maka dilakukan dengan cara aseptis.

Uji Antagonis Trichoderma sp terhadap Alternaria porri: Disiapkan media PDA (Potato Dextro Agar) dengan $\mathrm{pH} \mathrm{4,8} \mathrm{dan} \mathrm{pH} 7$ pada cawan petri yang berdiameter $9 \mathrm{~cm}$ dengan jarak $3 \mathrm{~cm}$. Kemudian disiapkan alkohol 70\%, jarum ose, wrapping dan diletakkan didalam LAF (Laminar Air Flow). Selanjutnya jamur Trichoderma sp dan Alternaria porri diambil menggunakan jarum ose dan dimasukkan kedalam cawan petri yang telah berisi media PDA. Cawan petri yang berisi jamur di bungkus dengan kertas sampul dan diberi label pada setiap perlakuan. Pengamatan dilakukan setiap hari sampai pertumbuhan jamur memenuhi media. Hasil pengamatan uji antagonis. Pertumbuhan jamur antagonis Trichoderma viride dan jamur patogen Alternaria porri diukur diameternya dengan 
menggunakan penggaris, dan hasil pengukuran persentase penghambatan dihitung menggunakan rumus sebagai berikut:

$$
P=\frac{r 1-r 2}{r 1} \times 100 \%
$$

Dimana: $\mathrm{P}=$ Persentase penghambatan jamur terhadap patogen

r1 = Panjang jari-jarii patogen pad aperlakuan kontrol

$\mathrm{r} 2=$ Panjang jari-jari patogen pada perlakuannuji antagonis [8]

Analisis data: Pengamatan dilakuakan pada kemampuan jamur Trichoderma viride dalam menghambat pertumbuhan jamur patogen Alternaria porri penyebab penyakit bercak ungu/putih keabuan pada tanaman bawang merah (Allium ascalonicum.L) dengan perlakuan $\mathrm{pH}$ berbeda yaitu $\mathrm{pH} 7$ dan $\mathrm{pH} 4,8$. Dan data dianalisis secara deskriptif yang disajikan dalam bentuk grafik dan tabel, juga disertai gambar dokumentasi. Analisis uji t pada kepercayaan $0,05=95 \%$ terhadap perlakuan $\mathrm{pH} 4,8$ dan $\mathrm{pH} 7$ ialah untuk mengetahui hasil beda rerata dari dua populasi data.

\section{Hasil dan Diskusi}

Isolasi Jamur Patogen Alternaria porri Pada Bagian Daun Tanaman Bawang: Hasil isolasi makroskopis dan mikroskopis jamur patogen Alternaria porri (Gambar 1):

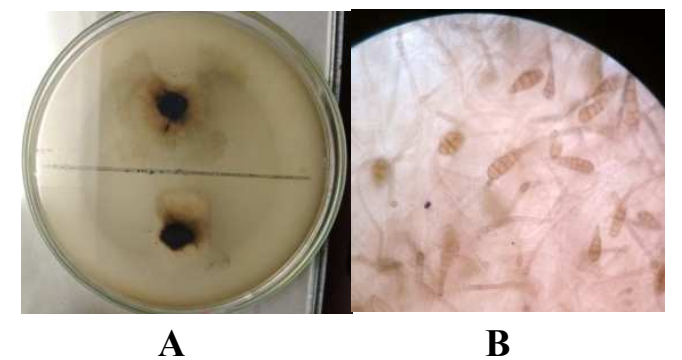

A
B
Gambar 1. Isolat jamur Alternaria porri secara A (Makroskopis) dan B (Mikroskopis) $40 \times 100 \mu \mathrm{m}$

Jamur Alternaria porri secara makroskopis yaitu memiliki ciri bahwa pada pertumbuhan awal jamur tersebut berwarna putih lalu setelah beberapa hari mulai berubah menjadi berwarna abu-abu kehitaman hingga hitam, koloni menyebar secara beraturan pada keseluruhan permukaan cawan petri [1]. Sedangkan morfologi jamur secara mikroskopis ciri-ciri nya yaitu memiliki misellium, konidium dan konidiofor yang berwarna coklat, konidiumnya berbentuk gada terbalik yang bersekat-sekat sedangkan konidiofornya tegak [9].

Isolasi Jamur Trichoderma viride pada Tanah Bagian Akar Tanaman Bawang Merah: Hasil jamur Trichoderma viride secara makroskopis dan mikroskopis (Gambar 2).

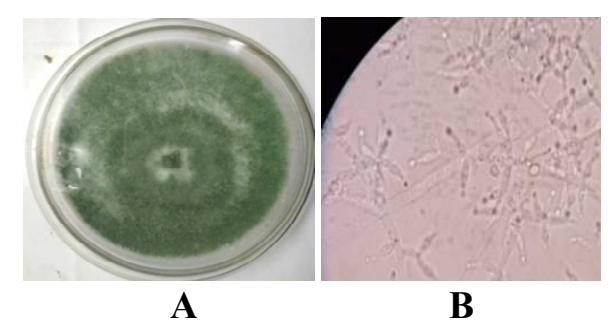

Gambar 2 : Isolat jamur Trichoderma viride secara $\mathbf{A}$ (Makroskopis) dan $\mathbf{B}$ (Mikroskopis) 40 x $100 \mu \mathrm{m}$.

Jamur secara makroskopis pada awal pertumbuhannya berwarna bening kemudian menjadi bulu tipis yang jarang dengan warna koloni putih, setelah beberapa hari koloni menjadi warna hijau karena terdapat kumpulan konidia pada bagian ujung hifa [5]. Dan secara mikroskopis memiliki ciri bahwa 
miselumnya bersepta, konidiofornya bercabang dan konidia bebentuk bulat atau oval yang berwarna hijau terang seperti bola berlendir [10].

Analisis Uji Antagonis Jamur Trichoderma viride Terhadap Jamur Patogen Alternaria porri: Antagonisme sendiri merupakan hubungan penghambatan suatu spesieas oleh spesias lain [11]. Sedangkan Uji antagonis merupakan suatu perlakuan yang bertujuan untuk mengetahui mekanisme dari isolat jamur Trichoderma viride dalam menghambat jamur patogen Alternaria porri dengan menunjukkan penghambatan yang telah terjadi pada suatu pertumbuhan jamur patogen. Pengamatan ini dilakukan dengan mengukur jari-jari jamur patogen Alternaria porri perlakuan kontrol dan juga jari-jari dari jamur Alternaria porri yang diuji antagonis dengan jamur Trichoderma viride. Pada pengamatan hari terakhir kemudian dihitung persentase daya hambat dari jamur Trichoderma viride terhadap patogen Alternaria porri untuk melihat potensi penghambatan dari jamur Trichoderma viride. Potensi penghambatan dapat diketahui dengan adanya mekanisme penghambatan.

\section{Uji Antagonis}

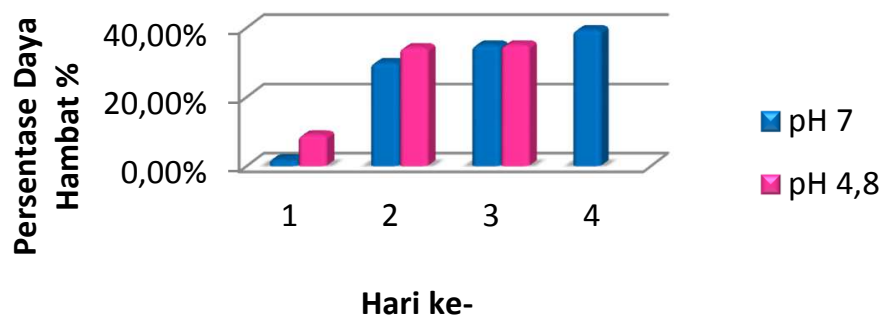

Gambar 3. Persentase daya hambat uji antagonis jamur Trichoderma viride terhadap jamur Alternaria porri

Persentase daya hambat uji antagonis berdasarkan dari grafik diatas menunjukkan bahwa jamur Trichoderma viride mampu menghambat patogen Alternaria porri dengan persentase daya hambat pada media PDA dengan $\mathrm{pH} 7$ pada hari ke-I yaitu 1,9\%, hari ke-II yaitu $29,9 \%$, hari ke-III $35 \%$ dan yang hari ke-IV 39,4\% sedangkan pada media PDA pH 4,8 pada hari ke-I yaitu 9\%, hari ke-II 34,2\% dan hari ke-III yaitu $35 \%$.

Dari hasil grafik persentase diatas menunjukkan bahwa perlakuan pada $\mathrm{pH} 4,8$ di hari ke 1-2 lebih besar dalam menghambat jamur patogen dibandingkan perlakuan $\mathrm{pH} 7$, hal ini terjadi dapat dikarenakan jamur lebih menyukai $\mathrm{pH}$ 4,8/rendah dibandingkan $\mathrm{pH} 7$ netral. Dan pada hari ke-3 kemampuan menghambat Trichoderma viride di $\mathrm{pH} 7$ dan $\mathrm{pH}$ 4,8 memiliki persentase penghambatan yang sama yaitu 35\%. Pertumbuhan optimum dari jamur Trichoderma yaitu pada $\mathrm{pH} 3,5-5,5$ karena pada $\mathrm{pH}$ ini lah jamur tersebut mampu mambentuk zat Antibiotika glitoksin [12]. Macam-macam mekanisme penghambatan pada uji antagonis Trichoderma viride terhadap patogen Alternaria porri ditunjukkan pada Gambar 4 dan 5.

Jamur antagonis Trichoderma viride yang diuji dengan jamur patogen Alternaria porri mampu menghambat dengan cara mekanisme inhibisi, mekanisme inhibisi juga dikenal dengan mekanisme antibiosis[8] Trichoderma sp mampu membentuk mekanisme inhibisi karena memiliki zat antibiotika glitoksin, dan senyawa toksik inilah yang dapat mempengaruhi dan bahkan menghambat sistem fungsional dari jamur patogen sehingga menjadi rentan [13]. Dan Trichoderma viride yang menghambat dengan mekanisme parasitisme yaitu mampu melisis jamur patogen dengan cara yaitu pada awal pertumbuhan hifa jamur antaagonis ini tumbuh memanjang lalu membelit dan mempenetrasi hifa jamur patogen sehingga hifa tersebut akhirnya hancur, mekanisme antagonisme jamur Trichoderma viride ini pada umumnya dalam menekan jamur patogen ialah sebagai mikoparasitik dan kompetitor yang agresif sehingga pada akhirnya melisis patogen [3]. 


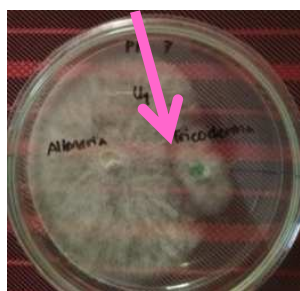

A

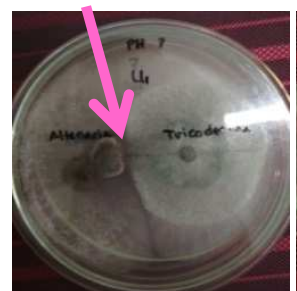

B

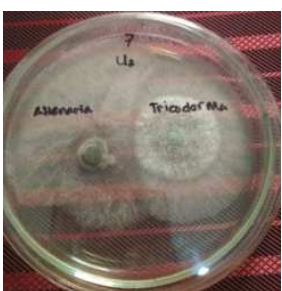

C

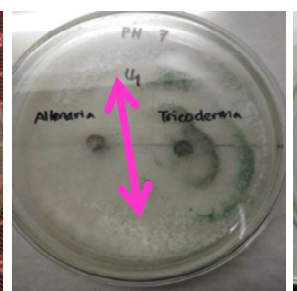

D

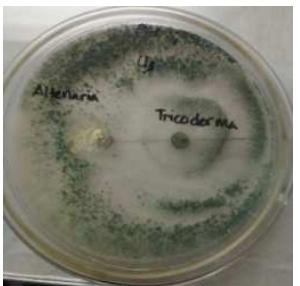

$\mathbf{E}$

Gambar 3. Macam mekanisme penghambatan pada uji antagonis $T$. viride terhadapa jamur patogen pada $\mathrm{pH}$ 7. Katerangan: (A) A.porri $><$ T.viride $\mathrm{pH} 7$ hari ke-2 terjadi penghambatan mekanisme antibiosis (zona inhibisi). (B) A.porri $><$ T. viride $\mathrm{pH} 7$ hari ke-3 terjadi penghambatan mekanisme antibiosis (zona inhibisi). (C) Hifa dari T.viride $\mathrm{pH} 7$ mulai memanjang dan memasuki sebagian hifa patogen A.porri. (D) T.viride $\mathrm{pH} 7$ hari ke-5 mulai terbentuk mekanisme parasitisme. (E) T.viride $\mathrm{pH} 7$ mampu memparasit dengan cara melisiskan patogen A.porri hingga hancur pada hari ke-7.

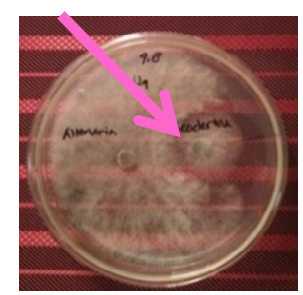

A

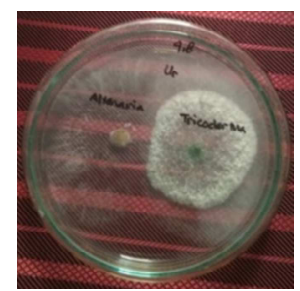

B

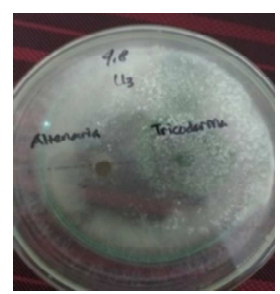

C

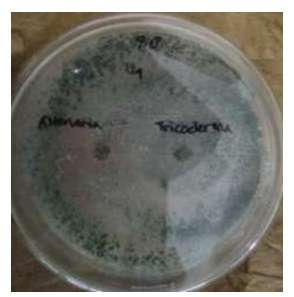

D

Gambar 5. Macam mekanisme penghambatan pada uji antagonis T. viride terhadapa jamur patogen pada $\mathrm{pH} 4,8$. Keterangan: (A) A.porri $><$ T.viride $\mathrm{pH} \mathrm{4,8} \mathrm{hari} \mathrm{ke-2} \mathrm{terjadi} \mathrm{penghambatan} \mathrm{mekanisme}$ antibiosis (zona inhibisi). (B) Hifa dari T.viride $\mathrm{pH} 4,8$ mulai memanjang dan memasuki sebagian hifa patogen A.porri. (C) T.viride $\mathrm{pH} \mathrm{4,8}$ hari ke-4 mulai terbentuk mekanisme parasitisme. (E) T.viride $\mathrm{pH}$

4,8 mampu memparasit dengan cara melisis patogen A.porri hingga hancur pada hari ke-7.

Mekanisme penghambatan jamur antagonis Trichoderma viride terhadap jamur patogen Alternaria porri terjadi dengan beberapa mekanisme, diantaranya antibiosis dimana mekanisme ini merupakan penghamabatan yang ditandai dengan terbentuknya zona inhibisi, selanjutnya mekanisme parasitisme yang mampu melisis jamur patogen dan ciri lisis yaitu hifa dari jamur antagonis memanjang kemudian membelit lalu mempenetrasi hifa dari jamur patogen sehingga hifa tersebut hancur. Berdasarkan beberapa dari mekanisme tersebut penghambatan isolat jamur antagonis yang diujikan pada patogen Alternaria porri dapat dikatakan merupakan jenis penghambatan inhibisi mutual, dimana mekanisme inhibisi mutual ini biasanya akan di ikuti oleh parasitisasi pada patogen, jadi interaksi jamur Trichoderma viride dan Alternaria porri dimulai dengan mekanisme antibiosi (Inhibisi) lalu pada akhirnya mampu memparasit Alternaria porri [8].

Pada analisa SPSS uji tabel $t$ diperoleh nilai probabilitas yaitu $0,589>0,05$ maka $\mathrm{pH}$ tidak berpengaruh terhadap perlakuan, dari perolehan nilai probabilitas ini dapat diketahui bahwa pada perlakuan $\mathrm{pH} 7$ atau $\mathrm{pH}$ 4,8 jamur Trichoderma viride sama-sama bisa menghambat jamur patogen. Dan nilai $t_{\text {tab }}$ dan $t_{\text {hit }}$ dengan menggunakan $(0,05)$ yaitu $t_{\text {hitung }}<t_{\text {tabel }}$ dengan nilai $0,571<1,043$ yang artinya tidak ada pengaruh/perbedaan terhadap $\mathrm{pH}$.

\section{Kesimpulan}

Pada penelitian dapat disimpulakan bahwa jamur Trichoderma viride mampu menghambat jamur patogen Alternaria porri dengan mekanisme penghambataan secara antibiosis, parasitisme dan 
e-Jurnal Ilmiah BIOSAINTROPIS (BIOSCIENCE-TROPIC)

Volume 5/ No.: 2 / Halaman 84 - 90 / Januari Tahun 2020

ISSN : 2460-9455 (e) - 2338-2805(p)

lisis. Trichoderma viride dalam melisis jamur patogen yaitu dengan cara hifa jamur antagonis ini di awal pertumbuhannya memanjang lalu membelit hifa jamur patogen hingga hancur. Persentase daya hambat uji antagonis yang diperoleh pada media PDA (Potato Dextrose Agar) $\mathrm{pH} 7$ dan pH 4,8 berbeda, dimana persentase daya hambat pada $\mathrm{pH} 7$ hari ke $1-2$ yaitu $1,9 \%$ dan $29,9 \%$, dan pada hari ke-4 yaitu 39,4\%. Sedangkan pada $\mathrm{pH} 4,8$ hari ke $1-2$ memiliki persentase $9 \%$ dan $34,2 \%$, dan pada hari ke-3 yaitu $35 \%$.

\section{Daftar Pustaka}

[1] Rachmatunnisa ,R., Rukmi, I., Pujiyanto, S. 2017. Aktivitas Antagonis Kapang Endofit Duwet (Syzygium cumini (L.)Skeels) Terhadap Alternaria porri Penyebab Bercak Ungu Pada Bawang Merah (Alium ascalonicum L.) Secara In-Vitro. Jurnal Biologi. Vol, 6. No, 1.

[2] Yuliani, F. 2017. Respon Morfologi Dan Fisiologi Tanaman Bawang Merah (Allium cepa L.) Terhadap Cekaman Salinitas. Tesis Institut Pertanian Bogor.

[3] Susandi, Y,N,K., Sualang, D,S., Paruntu, M,H,B. 2014. Antagonisme Trichoderma sp. Terhadap Alternaria porri Patogen Penyakit Bercak Ungu Tanaman Bawang Merah Pada Beberapa Media. Jurnal Agroekoteknologi. Universitas Samratulangi.

[4] Pitasari, A., dan Ali, M. 2018. Isolasi Dan Uji Antagonis Bakteri Endofit Dari Tanaman Bawang Merah (Allium ascalonicum L.) Terhadap Jamur Alternaria porri Ellis Cif. Jurnal JOM Faperta. Vol, 5. No, 1.

[5] Saputri,R. 2018. Penambahan Nutrisi PDA Pada Pembuatan Strarter Mikroorganisme Total Jamur dengan Bahan Baru Tepung Beras. Skripsi Universitas Islam Malang.

[6] Nawfetrias, W., Nurhangga, E., Sutardjo. 2016. Pemanfaatan Biofungisida Berbahan Aktif Trichoderma sp. Untuk Pengendalian penyakit Busuk Buah Kakao. Jurnal Bioteknologi \& Biosains Indonesia. Vol,3. No, 1. ISSN $2442-2606$.

[7] Dwiastuti, M.E., Budiarta,G.N.K., Soesanto, L. 2107. Perkembangan Penyakit Diplodia pada Tiga Isolat Botryodiplodia theobromae Path dan Peran Toksin Dalam Menekan Penyakit pada Jeruk (Citrus spp.) Jurnal Hort. Vol. 27 No. 2.1.

[8] Lelana, EN., Anggraeni,I., Mindawati, N. 2015. Uji Antagonis Aspergillus sp. Dan Trichoderma spp. Terhadap Fusarium sp., Penyebab Penyakit Rebah Kecambah Pada Sengon. Jurnal Penelitian Hutan Tanaman Vol. 12 No. 1, April 2015: 23-28

[9] Manihuruk, G. 2007. Uji Efektifitas Pestisida Nabati untuk Mengendalikan Penyakit Bercak Ungu (Alternaria porri Ell. Cif) pada Bawang Merah (Alium ascalonicum L.) di Lapangan. Skripsi Universitas Sumatera Utara. Medan.

[10] Resita, E.T. 2006. Produksi Selo-oligosakarida dari Fraksi Selulosa Tongkol Jagung Oleh selulosae Trichoderma viride. Skripsi. Institut Pertanian bogor : Bogor.

[11] Syauqi, A. 2017. Mikrobiologi Lingkungan Peranan Mikroorganisme dalam Kehidupan. AndiUnisma. Yogyakarta.

[12] Gultom, J,M. 2008. Pengaruh Pemberian Beberapa Jamur Antagonis dengan Berbagai Tingkat Konsentrasi untuk Menekan Perkecambahan Jamur Pythium sp. penyebab Rebah Kecambah Pada Tanaman Tembakau (Nicotiana tabaccum L.). Skripsi Universitas Sumatera Utara. Medan.

[13] Ainy, Q.E., Ratnayani, R., Susilawati, L. 2015. Uji Aktivitas Antagonis Trichoderma harzianum 11035 Terhadap Colletotrichum capsici TCKR2 dan Colletotrichum acutatum TCKI Penyebab Antraknosa pada Tanaman Cabai. SP-018-11. Jurusan Biologi Fakultas Sains dan Teknologi UIN Sunan Kalijaga. Yogyakarta. 